\title{
Phenotypic variation in the phenology of ascospore production between European populations of oak powdery mildew
}

\author{
Benoit MARÇAIS ${ }^{1 *}$, Miloslava KaVKova ${ }^{2}$, Marie-Laure DeSPREZ-LoustaU ${ }^{3}$ \\ ${ }^{1}$ INRA, Nancy Université, UMR1136 Interactions Arbres-Microorganismes, 54240 Champenoux, France \\ ${ }^{2}$ INRA, UMR1202 Biogeco, Équipe Pathologie forestière, 71 avenue Edouard Bourleaux, 33140 Villenave d'Ornon, France \\ ${ }^{3}$ University of South Bohemia, Faculty of Biology, Dpt. of botany, Na Zlaté Stoce 1, 38005, České Budějovice, Czech republic
}

(Received 23 January 2009; revised version 10 April 2009; accepted 12 May 2009)

\author{
Keywords: \\ plant pathogen / \\ forest tree / \\ Erisyphe alphitoides / \\ Quercus / \\ phenology \\ synchrony
}

\begin{abstract}
- Oak powdery mildew severity (Erysiphe alphitoides) is usually mild in Europe because epidemics start late in spring, at the end of the first oak growth unit maturation. However, the disease can occasionally be very severe when strong infection occurs early during the development of the first growth unit, suggesting that host-pathogen synchrony in spring could be a critical factor in disease severity.

- We studied the timing of ascospore production in a given environment for four E. alphitoides populations sampled from SW France to the Czech Republic to determine whether this trait shows variation within Europe.

- Timing of ascospore production was clearly influenced by environmental factors as chasmothecia from a single origin showed very different dates of optimal ascospore production when transferred for overwintering in locations with different climate. In common garden experiments, no differences were observed between populations for the date of optimal ascospore production.

- Results suggest little genetic differentiation for timing of ascospore production for E. alphitoides populations across Europe and therefore a lack of local adaptation to their host phenology. Availability in ascospore inoculum is limited during host budburst, explaining the low infection usually observed on the first oak growth unit.
\end{abstract}

Résumé - Variabilité phénotypique dans la phénologie de la production d'ascospores entre populations européennes d'ö̈dium du chêne.

- L'oïdium du chêne (Erysiphe alphitoides) est généralement peu sévère en Europe, la maladie se développant tard au printemps, après le débourrement des chênes. E. alphitoides peut toutefois être sévère quand de fortes infections se produisent tôt durant le débourrement, suggérant que la synchronisation entre hôte et pathogène pourrait être un facteur déterminant la sévérité des épidémies.

- Nous avons caractérisé la dynamique de production d'ascospores dans un environnement donné pour quatre populations d'E. alphitoides échantillonnées du sud-ouest de la France à la République Tchèque pour tester si ce trait est variable en Europe.

- Des chasmothèces d'une même origine présentent des dates d'optima de production d'ascospores très différentes quand elles sont transférées durant l'hiver dans des zones à climats différents montrant que ce trait est sous dépendance de l'environnement. Par contre, les quatre populations ont la même date d'optimum de production d'ascospores quand elles sont placées dans un même environnement. - Les résultats suggèrent que les populations d'E. alphitoides européennes ne sont pas différentiées génétiquement pour le timing de production d'ascospores et donc qu'elles ne sont pas localement adaptées à la phénologie de leur hôte. L'inoculum ascospores est très peu présent durant le débourrement, expliquant en partie l'absence d'infection sur la première unité de croissance des chênes.

\section{INTRODUCTION}

It has been shown that synchrony between parasites and their host phenology can be very important for organisms that specialise on an ephemeral resource such as developing

\footnotetext{
* Corresponding author: marcais@ nancy.inra.fr
}

leaves, in particular defoliating insects (Van Asch and Visser, 2007). For fungal pathogens, synchrony of spore production and of production of susceptible tissues by the host can also determine the severity of diseases (Baker et al., 2005; Biere and Honders 1996; Desprez-Loustau et al., 1994; Penman and Annis 2005). A better understanding of host/parasite 
phenological synchrony is especially important in the context of climate change as it is well known that plant phenology can be strongly affected by climate warming (Cleland et al., 2007). It was also shown that phenology of the poplar rust, Melampsora larici-populina, has changed in the past decade with a advanced infection of larch by the rust basidiospores (DesprezLoustau et al., in press). For plants, it has been demonstrated that the environmental control of budburst is not always similar for different populations of a species. Indeed, plant populations are known to adapt to local climate and to show genetic differentiation for their phenology across large areas; this is in particular the case for oaks in Europe (Ducousso et al., 1996; Jensen and Hansen 2008). Comparatively, very little is known about environmental factors involved in plant pathogen phenology and how environmental control of this phenology may change across populations of a pathogen species, although some examples show it can be very important in disease development (Lehman and Oudemans 2000; Scherm et al. 2001). Thus, studying phenological synchrony for pathogens of forest trees requires a better understanding of factors that control pathogen phenology.

Oak powdery mildew caused by Erysiphe alphitoides, an exotic pathogen first mentioned in Europe in 1907, is a very common disease of pedunculate (Quercus robur) and sessile (Q. petraea) oaks in Europe (Foex, 1941). The disease can be very severe, especially in young regenerations where it reduces growth and causes seedling mortality (Soutrenon, 1998). On mature trees, the disease is generally far less damaging although it can reduce tree vigour in conjunction with other factors such as defoliation by insects and contribute to tree decline (Marçais and Bréda, 2006; Thomas et al., 2002). Most often, the disease develops quite late in spring, at the end of the maturation of the first oak growth unit. As only young developing leaves are susceptible to infection by E. alphitoides (Edwards and Ayres, 1982), the disease is especially prevalent on the second and third growth units that develop between end of June and August. This strongly mitigates the severity of the disease on large trees as the first growth unit represents the major part of the leaf area index on mature oaks (Bréda et al., 1995). However, the French forest health survey system reported severe infection on mature oak trees in several recent years in South West France that in some cases could trigger tree decline. This appeared to be linked with early occurrence of the pathogen in the growing season and severe infection of the first growth unit of oaks in years with warm winter.

An earlier start of the oak mildew epidemic in spring could be linked to a higher availability in primary inoculum or to more suitable conditions for disease development. However, availability of inoculum during the development of the first oak growth unit is not known. Two different sources of $E$. alphitoides inoculum in spring have been reported. Flag shoots, i.e. infected shoots formed from the development of buds colonised by the pathogen in the previous summer, have been described for oak mildew (Kerling, 1966), but are very infrequent (Marçais, unpublished results) and do not appear to represent substantial inoculum sources in spring. Ascospores released from chasmothecia should be a more frequent source of inoculum as chasmothecia are abundantly formed on infected leaves in autumn. However, the phenology of chasmothecia, i.e. the timing of ascospore production has not been studied and whether ascospore inoculum is available during the oak budburst is not known.

The aim of this work was to study whether the timing of ascospore production in spring by E. alphitoides chasmothecia is under environmental control and whether populations from different European areas exhibit differences in environmental control for this trait. For that, we did (i) a population transfer experiment by comparing the timing of ascospore production by chasmothecia of a single E. alphitoides population placed under different environments for overwintering; (ii) common-garden experiments comparing the timing of ascospore production by chasmothecia of E. alphitoides populations of different geographical origins overwintered under common environmental conditions. The common garden approach is commonly used to detect signatures of genetic, likely adaptive, differentiation between populations for a wide range of traits and species (e.g. Cipollini 2002; Oleksyn et al. 1998).

\section{MATERIALS AND METHODS}

\subsection{Fungal and plant material}

The powdery mildew populations studied were sampled on a west to east gradient in Europe from SW France to the Czech Republic. The chasmothecia were collected on leaves of Quercus robur and/or Q. petraea in 3 different locations in fall of 2005 and 2006, Cestas (SW France, close to Bordeaux, $44^{\circ} 45^{\prime} 32^{\prime \prime} \mathrm{N}, 00^{\circ} 42^{\prime} 36^{\prime \prime} \mathrm{W}$ ), Fontainebleau (central France, $02^{\circ} 58^{\prime} 37^{\prime \prime} \mathrm{N}, 48^{\circ} 20^{\prime} 51^{\prime \prime} \mathrm{W}$ ) and Champenoux (NE France, close to Nancy, $48^{\circ} 45^{\prime} 06^{\prime \prime} \mathrm{N}$, $06^{\circ} 20^{\prime} 18^{\prime \prime} \mathrm{E}$ ) and an additional fourth location in fall of 2005, Ceske Budejovice (SW Czech Republic, $48^{\circ} 57^{\prime} 30^{\prime \prime} \mathrm{N}, 14^{\circ} 28^{\prime} 30^{\prime \prime} \mathrm{E}$ ). Mean annual temperature was $8.2{ }^{\circ} \mathrm{C}, 9.0^{\circ} \mathrm{C}, 9.9^{\circ} \mathrm{C}$ and $13.3{ }^{\circ} \mathrm{C}$ for Ceske Budejovice, Champenoux, Fontainebleau and Cestas respectively. Leaves severely infected by oak mildew were collected from oaks in natural stands or in nursery conditions just before leaf shedding. They were brought back to the laboratory and were examined under a binocular microscope for the presence of chasmothecia. These were most predominantly of the Erysiphe (section Microsphaera) morphotype, with dichotomously branched appendages; a few Phyllactinia (of bigger size and with straight, non branched appendages) were very seldom observed. Since several Erysiphe species can be found on oaks (Mougou et al., 2008), we analysed ITS from a sample of chasmothecia from each origin using the technique described in Mougou et al. (2008) $(n=4-20)$. Only E. alphitoides was present in the analysed samples.

$Q$. robur seedlings were grown to be used as selective traps for ascospore production by chasmothecia. In experiment 1 and 3 (see below), trap plants were germinating oak seedlings of the provenance Amance, NE France, grown in greenhouse conditions in pots of $2 \mathrm{~L}$ filled with a 50/50 mix of peat/sand (18 seedlings per pot). In experiment 2, the provenance was Vallée de la Saône, NE France, and seedlings were grown in greenhouse conditions in $0.5 \mathrm{~L}$ pots (diameter $=10 \mathrm{~cm}, \mathrm{~h}=18 \mathrm{~cm}$ ) filled with a peat $/$ sand $/$ perlite substrate (Klasmann RHP15). 


\subsection{Population transfer (Exp. 1)}

In experiment 1 , we compared the timing of ascospore production of chasmothecia of the Champenoux origin overwintered in 3 different locations in France.

Immediately after collection in the fall, oak leaves bearing high numbers of chasmothecia were brushed onto $20 \mathrm{~cm}$ Petri dishes to harvest chasmothecia, which were then put into Nylon mesh bags. Several bags with approximately 400 chasmothecia were prepared. The number of chasmothecia per bag was estimated by weighing, using the weight of 500 chasmothecia that was previously determined. Bags containing chasmothecia were placed in outdoor conditions in the beginning of November 2006 for overwintering in Nancy INRA research station $\left(48^{\circ} 45^{\prime} 06^{\prime \prime} \mathrm{N}, 06^{\circ} 20^{\prime} 18^{\prime \prime} \mathrm{E}\right.$, NE France), Bordeaux INRA research station ( $44^{\circ} 46^{\prime} 50^{\prime \prime} \mathrm{N}, 0^{\circ} 33^{\prime} 57^{\prime \prime} \mathrm{W}$, SW France) and Gedre, an oak stand located in the Pyrénées at an elevation of $1251 \mathrm{~m}$ $\left(42^{\circ} 47^{\prime} 18^{\prime \prime} \mathrm{N}, 00^{\circ} 01^{\prime} 47^{\prime \prime} \mathrm{E}\right)$. The overwintering samples were suspended to a pole in plastic meshes allowing them to be exposed to sun and rain.

In spring, starting beginning of April and until end of June, chasmothecia from each overwintering location were sent weekly by mail to the Nancy INRA research station to determine the proportion of chasmothecia able to produce ascospores in laboratory conditions. Only one nylon mesh bag containing chasmothecia was sampled for each overwintering location * test time combination. The samples were processed within 2-3 d after arrival at the research unit. Of the initial 400 chasmothecia put in the bags in autumn, few in apparently good condition (not decomposed, with appendages present) could be recovered. Depending on availability, 36 to 72 chasmothecia per sample were isolated with a needle under the binocular and placed in Petri dishes. Moistened blotting papers were sterilised $\left(120{ }^{\circ} \mathrm{C}\right.$ during $20 \mathrm{~min}$ ) and laid down in the cover of water agar containing Petri dishes (15 $\mathrm{g} \mathrm{L}^{-1}$ agar). Nine chasmothecia were placed onto the moistened blotting paper in each Petri dish. The dishes were then incubated at $20{ }^{\circ} \mathrm{C}$ in $16 \mathrm{~h} \mathrm{light} / 8 \mathrm{~h}$ dark conditions for $7 \mathrm{~d}$. After that period, the agar surface was examined under a binocular microscope for ascospores. These were identified as very bright appearing spores clustered under chasmothecia. The proportion of chasmothecia that had produced ascospores was computed at each test date (one proportion over all dishes). To check that we were indeed observing oak mildew ascospores in the in vitro test, the mesh containing the remaining of the chasmothecia sample was placed over trap oak seedlings in the laboratory at room conditions at the same time as chasmothecia were placed in Petri dishes. For each chasmothecia origin tested, 18 1-month-old $Q$. robur were exposed to the mesh which was placed at 10-20 cm over the seedlings for one week and sprayed by water each $2-3 \mathrm{~d}$.

\subsection{Common garden (Exp. 2 and 3)}

In experiments 2 and 3 , the timing of ascospore production in spring by chasmothecia from different origins was monitored in 2 common gardens by 2 different techniques.

In experiment 2 , chasmothecia of different origins were collected and overwintered during 2 successive years at the Nancy INRA research station as described for experiment 1 . In 2006, 3 of the studied origins, Cestas, Champenoux and Ceske Budejovice were used while in 2007, only 2 of the origins, Cestas and Champenoux were used. In spring, starting beginning of April and until end of June, chasmothecia from each origin were sampled weekly to determine the propor- tion of chasmothecia able to produce ascospores in laboratory conditions. Just one nylon mesh bag containing chasmothecia was sampled for each overwintering location * test time combination. The samples were processed as described for experiment 1 .

In experiment 3 , chasmothecia of different origins were overwintered during $2 \mathrm{y}$ at the Bordeaux INRA research station. The 4 studied origins were used in 2006 while only 3 were used in 2007 (Cestas, Fontainebleau, and Champenoux). Immediately after collection in the fall, oak leaves bearing high numbers of chasmothecia were directly put in Nylon mesh bags with a mesh size of $50 \mu \mathrm{m}$. Several bags with approximately 40 leaves were prepared per origin and were placed in outdoor conditions in the beginning of November 2005 and 2006 for overwintering. The overwintering samples were placed on $1 \mathrm{~m}$-high horizontal wire mesh frames allowing them to be exposed to sun and rain.

Timing of spore production by chasmothecia was monitored by studying ascospore-derived infections on trap seedlings placed under the chasmothecia in the spring. In March 2006 and 2007, leafcontaining bags were put on horizontal wire-mesh frames (height $=$ $0.80 \mathrm{~m}$, width $=0.50 \mathrm{~m}$, length $=0.50 \mathrm{~m}$ ) in outdoor cages made of unwoven material (Fiberweb agryl P30) in order to prevent exposure to local oak mildew inoculum. From the beginning of April to the end of June, young $Q$. robur seedlings were exposed to the chasmothecia of the different origins for periods of $10 \mathrm{~d}$. For each origin, only one cage was used; the cage contained 12 seedlings per exposure period and was covered with 6 leaf-containing bags. Trap seedlings were carefully selected among the greenhouse grown material according to their phenological stage: only seedlings presumed to be highly susceptible to powdery mildew, i.e. with young, non fully developed leaves, were taken. A control cage with no leaf-containing bag was included in each test.

In both 2006 and 2007, experiment 3 also included tests in a climatic chamber $\left(18 / 22{ }^{\circ} \mathrm{C}, 8 / 16 \mathrm{~h}\right.$ night-day photoperiod). Trap oak seedlings were exposed to the chasmothecia - bearing leaves as previously explained except that the sample consisted of a smaller number of leaves than in the outdoor test. In order to allow chasmothecia to continue their maturation under natural conditions, one leaf-containing bag per origin was taken from outdoors to the climatic chamber at each test date. During the 10-d exposure period, six 2-mm rain episodes were simulated by spraying water above the chasmothecia-bearing leaves, covered with a filter paper. This test was performed with the Cestas and Champenoux origin in 2006 and with the Cestas and Fontainebleau origin in 2007.

After the 10-d exposure period, either outdoors or in climatic chamber, the trap seedlings were incubated for $10 \mathrm{~d}$ in a growth chamber $\left(18 / 22{ }^{\circ} \mathrm{C}, 8 / 16 \mathrm{~h}\right.$ night-day photoperiod). They were then observed to evaluate the number of $E$. alphitoides infections. All leaves of the exposed seedlings were examined and the overall number of powdery mildew colonies, visible as white spots, on the 12 seedlings was counted.

\subsection{Data analysis}

The relationship between time and proportion of chasmothecia producing ascospores in vitro or number of ascospore-derived infections on trap oak seedlings outdoors or in climatic chamber was studied. Time was set as the middle of the period of exposure, i.e. medium date (expressed as day of year) between the date when chasmothecia were put on the Petri dishes and the date when ascospore production was recorded (experiments 1 and 2) or of the dates of beginning 
and end of the trap seedlings exposure to the chasmothecia-bearing leaves (Exp. 3). Thus, the times of optimum in ascospore production inferred from the two used methods are directly comparable.

For production of ascospores in vitro in experiment 1 , the model used was a logistic model with a quadratic effect:

$$
N_{\text {prod }}=N \times \frac{\exp \left(b_{0}+b_{i} \times O w_{i}+a \times\left(t-c_{0}-c_{i} \times O w_{i}\right)^{2}\right)}{\left(1+\exp \left(b_{0}+b_{i} \times O w_{i}+a \times\left(t-c_{0}-c_{i} \times O w i\right)^{2}\right.\right.}
$$

with $N_{\text {prod }}$, the number of chasmothecia that produced ascospores, $N$, the number of tested chasmothecia, $t$, the time in day of year (DOY) and $O w_{i}$, the overwintering location (INRA-Bordeaux, INRA-Nancy and Gedre).

The expected curve is a bell-shaped curve with an optimum of ascospore production at a DOY of $c_{0}+c_{i} \times O w_{i}$. To assess whether the optimum time was different at different overwintering locations, we compared model (1) to the following reduced model:

$$
N_{\text {prod }}=N \times \frac{\exp \left(b_{0}+b_{i} \times O w_{i}+a \times\left(t-c_{0}\right)^{2}\right)}{\left(1+\exp \left(b_{0}+b_{i} \times O w_{i}+a \times\left(t-c_{0}\right)^{2}\right)\right.} .
$$

The same procedure was also applied in experiment 2 to test whether chasmothecia of different origin (Cestas, Champenoux, Ceske Budejovice) had a similar time for the ascospore production optimum. The overwintering location effect was replaced by a origin effect and a year effect was included, as experiment was repeated in 2006 and 2007. The full model was:

$$
\begin{aligned}
& N_{\text {prod }}=N \times \\
& \frac{\exp \left(b_{0}+b_{i} \times \mathrm{Yr}_{i}+c_{i} \times \mathrm{Or}_{i}+a \times\left(t-d_{0}-d_{i} \times \mathrm{Yr}_{i}-e_{i} \times \mathrm{Or}_{i}\right)^{2}\right)}{\left(1+\exp \left(b_{0}+b_{i} \times \mathrm{Yr}_{i}+c_{i} \times \mathrm{Or}_{i}+a \times\left(t-d_{0}-d_{i} \times \mathrm{Yr}_{i}-e_{i} \times \mathrm{Or}_{i}\right)^{2}\right)\right.}
\end{aligned}
$$

with $\mathrm{Yr}_{i}$, the year of the experiment and $\mathrm{Or}_{i}$, the origin.

For ascospore-derived infections on the trap oak seedlings in experiment 3 , the model used was:

$$
\mu=\exp \left(b_{0}+b_{i} \times \mathrm{Yr}_{i}+c_{i} \times \mathrm{Or}_{i}+\operatorname{Con}_{i}+a \times\left(t-d_{0}-d_{i} \times \mathrm{Yr}_{i}-e_{i} \times \mathrm{Or}_{i}\right)^{2}\right)
$$

with $\mu$, the number of mildew colonies on the trap seedlings, $t$, the time in DOY, $\mathrm{Yr}_{i}$ the year of the test $(2006,2007), \mathrm{Con}_{i}$, the test conditions (outdoors, climatic chamber) and $\mathrm{Or}_{i}$, the chasmothecia origin (Cestas, Fontainebleau, Champenoux or Ceske Budejovice).

The expected curve is a modal curve with an optimum of the maximal number of colonies on seedlings exposed to chasmothecia at a DOY of $d_{0}+d_{i} \times \mathrm{Yr}_{i}+e_{i} \times \operatorname{Pr}_{i}$. To test for a difference in the optimum of the 4 different origins, this model was compared to the following reduced model:

$$
\mu=\exp \left(b_{0}+b_{i} \times \mathrm{Yr}_{i}+c_{i} \times \operatorname{Pr}_{i}+\operatorname{Con}_{i}+a \times\left(t-d_{0}-d_{i} \times \mathrm{Yr}_{i}\right)^{2}\right) .
$$

The same procedure was used to test the Year effect.

Models were fitted with the nls procedure of $R$. Whether the models (1) or (2) better explained the data than the sub models (4) or (5) was tested with the anova procedure of $R$.

\section{RESULTS}

\subsection{Population transfer (Exp. 1)}

In 2007, chasmothecia from the origin Champenoux had very different timing of spore production when overwintered

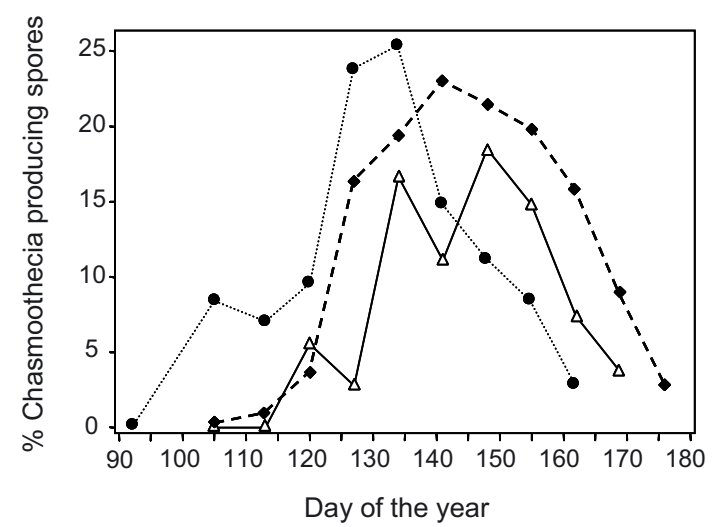

Figure 1. Production in vitro of ascospores by chasmothecia from origin Champenoux over wintered in different places in France

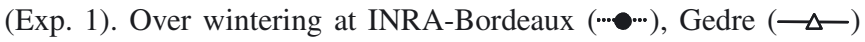
and INRA-Nancy (-ヶ).

Table I. Non linear model fitted on the dynamics of ascospore production by chasmothecia of Champenoux origin over wintered in different locations (Exp. 1).

\begin{tabular}{ccc}
\hline Model (1) parameter & Value & Confidence interval \\
\hline$b_{0}$ & -0.15 & $(-1.26 ;-1.04)$ \\
$b_{\text {Gedre }}$ & -0.45 & $(-0.88 ;-0.02)$ \\
$b_{\text {Bordeaux }}$ & -0.15 & $(-0.34 ; 0.04)$ \\
$a$ & -0.0025 & $(-0.0030 ;-0.0020)$ \\
$c_{0}$ & 145.2 & $(143.4 ; 147.0)$ \\
$c_{\text {Gedre }}$ & 0.56 & $(-6.51 ; 7.64)$ \\
$c_{\text {Bordeaux }}$ & -12.08 & $(-15.70 ;-8.47)$ \\
\hline
\end{tabular}

$b_{\text {Gedre }}, b_{\text {Bordeaux }}, c_{\text {Gedre }}, c_{\text {Bordeaux }}$, contrast for chasmothecia over wintering respectively in Gedre, in the Pyrénées and INRA-Bordeaux compared to chasmothecia over wintering in INRA-Nancy. Model $F$ is of 147.5 $(p<0.0001)$.

at INRA-Bordeaux, INRA-Nancy or Gedre, in the Pyrénées (Fig. $1, F=22.2, d f=2, p<0.001$ ). The fitted model parameters are given in Table I. The difference was mainly between overwintering in Bordeaux or in the 2 other locations, while timing of ascospore production was similar for chasmothecia overwintered in Nancy or in Gedre (Tab. I, $c_{\text {Bordeaux }}$ significantly different from 0 and $C_{\text {Gedre }}$ not significantly different from 0 ). Powdery mildew infections on the trap oak seedlings were observed 6-8 d after the first observation of ascospores in vitro, confirming that we were indeed observing oak mildew ascospores. The estimated day of optimum ascospore production was respectively $133.1 \pm 3.0,145.2 \pm 1.7$ and $145.8 \pm 6.5$ for chasmothecia overwintered in Bordeaux, Nancy or Gedre. Average temperature from beginning of December to end of April was respectively of $4.3{ }^{\circ} \mathrm{C}, 0.6{ }^{\circ} \mathrm{C}$ and $-0.1{ }^{\circ} \mathrm{C}$ and monthly rain respectively of 70.7, 52.2 and $85.7 \mathrm{~mm}$ in INRABordeaux, INRA-Nancy and Gedre. Thus, mean winter temperature appeared to be linked to the date of optimal ascospore production. 

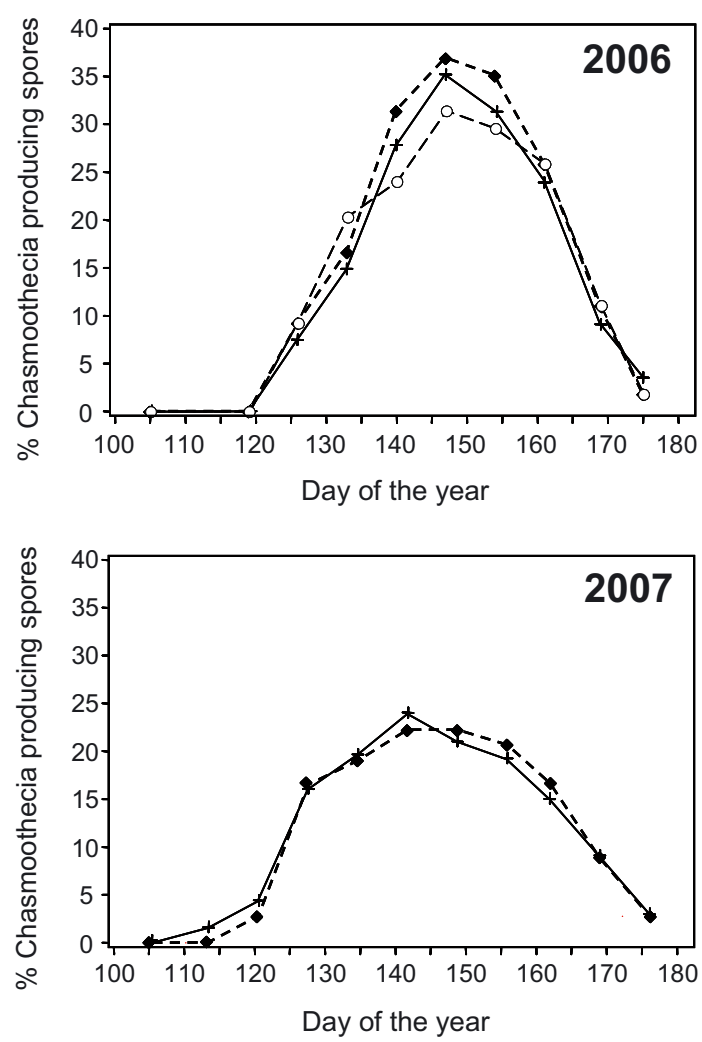

Figure 2. Production in vitro of ascospores by chasmothecia over wintered in common garden at INRA-Nancy (Exp. 2). Origin Cestas $(\multimap)$, Ceske Budejovice (-๑) and Champenoux (-ヶ ).

\subsection{Common garden (experiment 2)}

The timing of ascospore production assessed in Petri dishes from chasmothecia of different origins overwintered at INRANancy is shown in Figure 2. Again, powdery mildew infections on the trap oak seedlings were observed 6-8 d after the first observation of ascospores in vitro. Very similar results were obtained for chasmothecia of the different origins both in 2006 and 2007 (Fig. 2). There was no significant difference in the date of maximal spore production between the chasmothecia of the 3 origins, Cestas, Champenoux and Ceske Budejovice $(F=0.01, d f=2, p=0.991)$. By contrast, the optimum ascospore production time was significantly different in the $2 \mathrm{y}$ of the experiment, with an optimum at $148.9 \pm 1.0 \mathrm{DOY}$ in 2006 and $144.5 \pm 1.4$ in 2007 ( $F=20.0, d f=1, p<0.001)$. The fitted model parameters are given in Table II (parameters $e_{\text {Ceske }}$ and $e_{\text {Bordeaux }}$ not significantly different from 0 while $d_{07}$ is significantly different from 0 ). Average temperature from beginning of December to end of April at INRA-Nancy was respectively of $-1.6{ }^{\circ} \mathrm{C}$ and $0.6{ }^{\circ} \mathrm{C}$ and monthly rain respectively of 33.6 and $52.2 \mathrm{~mm}$ in 2006 and 2007.

\subsection{Common garden (Exp. 3)}

Figure 3 shows the number of powdery mildew colonies in 2006 and 2007 on trap oak seedlings at INRA-Bordeaux
Table II. Non linear model fitted on the dynamics of ascospore production by chasmothecia of different origins over wintered in a common garden (Exp. 2).

\begin{tabular}{ccc}
\hline Model 3 parameter & Value & Confidence interval \\
\hline$b_{0}$ & -0.62 & $(-0.73 ;-0.50)$ \\
$b_{07}$ & -0.44 & $(-0.56 ;-0.32)$ \\
$c_{\text {Ceske }}$ & -0.14 & $(-0.30 ;-0.01)$ \\
$c_{\text {Cestas }}$ & -0.08 & $(-0.20 ; 0.04)$ \\
$a$ & -0.0031 & $(-0.0034 ;-0.0027)$ \\
$d_{0}$ & 148.2 & $(146.9 ; 149.5)$ \\
$d_{07}$ & -3.25 & $(-4.58 ;-1.91)$ \\
$e_{\text {Ceske }}$ & -0.09 & $(-2.39 ; 2.21)$ \\
$e_{\text {Cestas }}$ & 0.06 & $(-1.74 ; 1.86)$ \\
\hline
\end{tabular}

$c_{\text {Cseke }}, c_{\text {Cestas }}, e_{\text {Ceeske }}$ and $e_{\text {Cestas }}$, contrast for respectively Ceske Budejovice and Cestas chasmothecia origin compared to the Champenoux origin and $b_{07}, d_{07}$ contrast for 2007 compared to 2006. Model $F$ is of 276.3 $(p<0.0001)$.

both in outdoor conditions and in climatic chamber. In 2006, data for control trap oak seedlings (encaged but not exposed to chasmothecia) were unavailable due to a technical problem. In 2007, despite a good efficacy of the cages in preventing infections from external inoculum (reduction of $84 \%$ at the peak of infections), the control trap seedlings showed substantial oak mildew infection. A corrected number of powdery mildew colonies on exposed seedlings was computed for 2007 data as $\max \left(0, n \mathrm{col}_{\text {exp }}-n \mathrm{col}_{\text {cont }}\right)$, with $n \mathrm{col}_{\text {exp }}$ the number of colonies on exposed seedlings and $n \mathrm{col}_{\text {cont }}$, the number of colonies on control seedlings at the same date. A preliminary analysis was performed to test whether the estimated date of maximal disease initiation on trap seedlings was influenced by the condition of the test, i.e. outdoors versus climatic chamber or by taking into account corrected versus uncorrected data. It showed that the estimates of the time of maximal disease initiation were not significantly different for trap seedlings exposed outdoors or in climatic chamber or when using corrected or uncorrected data $(F=1.71, d f=2, p=0.191)$. In 2006 also, the estimate of the time of maximal disease initiation was not significantly different for seedlings exposed outdoors or in climatic chamber $(F=1.84, d f=1, p=0.186)$. Thus, external inoculum-derived infections on the trap seedlings in the outdoor cages did not induce bias in the estimation of the time of the maximal disease initiation and we used uncorrected data to accommodate both 2006 and 2007 data in one analysis (model (3)).

The origin of chasmothecia had no significant effect on the date of the maximal disease initiation on trap oak seedlings (Fig. 3, $F=0.31, d f=3, p=0.820$ ). By contrast, the maximal disease initiation occurred at different dates in 2006 and $2007(F=28.63, d f=1, p<0.001)$, with a maximum at $143.9 \pm 1.1 \mathrm{DOY}$ in 2006 and at $133.4 \pm 1.0$ in 2007. This latter value is very close to that obtained for maximal ascospore production in experiment 1 for chasmothecia over wintered at INRA-Bordeaux (133.1, cf. above). The fitted 

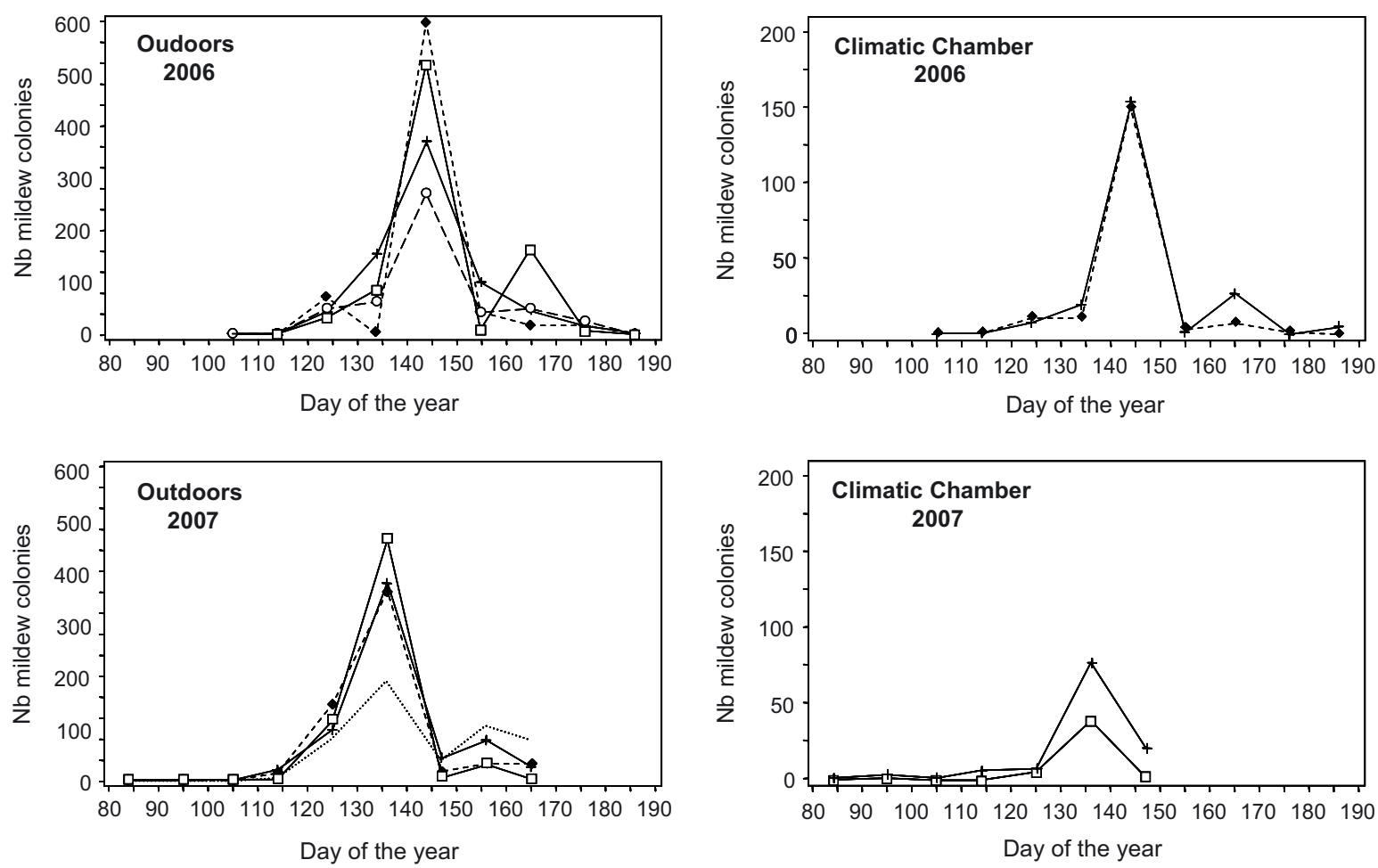

Figure 3. Number of powdery mildew colonies initiated on trap oak seedlings placed under chasmothecia of different origins over wintered in common garden at INRA-Bordeaux (Experiment 3). Origin of Cestas ( + ), Ceske Budejovice ( $\bullet$ ), Fontainebleau ( $\square-)$ and Champenoux (-ヶ ); control for outdoors conditions (......).

model parameters are given in Table III (parameter $e_{\text {Champenoux }}$, $e_{\text {Fontainebleau }}$ and $e_{\text {Ceske }}$ not significantly different from 0 while $d_{07}$ is). Average temperature from beginning of December to end of April at INRA-Bordeaux was respectively of $3.2^{\circ} \mathrm{C}$ and $4.3^{\circ} \mathrm{C}$ and monthly rain respectively of 102.2 and $70.7 \mathrm{~mm}$ in 2006 and 2007.

\section{DISCUSSION}

The timing of ascospore production in spring by E. alphitoides chasmothecia was clearly influenced by external factors (different climates in years and locations of over wintering) but not by the geographical origin of the chasmothecia. Although few replicates were done in each individual test, the whole study was replicated 4 times, in 2 different locations with 2 different techniques and over $2 \mathrm{y}$, with consistent results. Studying populations of different geographic origins under a common environment is a widely used methodology to detect signatures of genetic, likely adaptive, differentiation. For example, this approach showed that oaks are genetically differentiated for spring budburst phenology, with a higher need for accumulated heat in more northern and eastern European populations (Ducousso et al, 1996; Jensen and Hansen 2008). The fact that all populations of chasmothecia showed the same timing of ascospore production under the same environmental conditions in our study is suggestive of a lack of genetic differentiation for this trait between populations of oak powdery
Table III. Non linear model fitted on the number of powdery mildew colonies initiated on trap seedlings exposed to chasmothecia of different origin placed in a common garden (Exp. 3).

\begin{tabular}{ccc}
\hline Model 4 parameter & Value & Confidence interval \\
\hline$b_{0}$ & 6.1 & $(5.9 ; 6.2)$ \\
$b_{07}$ & -0.1 & $(-0.3 ; 0.1)$ \\
$c_{\text {Champenoux }}$ & 0.3 & $(0.1 ; 0.4)$ \\
$c_{\text {Fontainebleau }}$ & 0.2 & $(0.1 ; 0.3)$ \\
$c_{\text {Ceske }}$ & -0.4 & $(-0.7 ;-0.1)$ \\
Con $_{\text {cc }}$ & -1.4 & $(-1.7 ;-1.1)$ \\
$a$ & 0.020 & $(-0.024 ;-0.016)$ \\
$d_{0}$ & 145.2 & $(143.7 ; 146.6)$ \\
$d_{07}$ & -11.2 & $(-12.7 ;-9.8)$ \\
$e_{\text {Champenoux }}$ & 1.2 & $(-0.3 ; 2.7)$ \\
$e_{\text {Fontainebleau }}$ & 0.6 & $(-0.9 ; 2.2)$ \\
e $_{\text {Ceske }}$ & 2.2 & $(-1.2 ; 5.5)$ \\
\hline
\end{tabular}

$c_{\text {Champenoux }}, c_{\text {Fontainebleau }}, c_{\text {Ceske }}, e_{\text {Nancy }}, e_{\text {Fontainebleau }}$ and $e_{\text {Ceske }}$, contrast for respectively Champenoux, Fontainebleau and Ceske Budejovice chasmothecia origin compared to the Cestas origin. $C$ on $_{\mathrm{cc}}$, contrast for climatic chamber conditions compared to outdoor conditions and $b_{07}, d_{07}$ contrast for 2007 compared to 2006. Model $F$ is of $102.9(p<0.0001)$.

mildew over a large SW to NE transect in Europe. Therefore, E. alphitoides populations are apparently not locally adapted to their host for phenological match despite what could be 
expected for a pathogen able to infect only an ephemeral resource such as developing leaves.

This means that no phenological synchrony between oak mildew and its host can be generally expected. For example, on the level 2 European network $(16 \times 16 \mathrm{~km}$ systematic network used to monitor forest condition in Europe), budburst of $Q$. robur and $Q$. petraea occurred on DOY 118 and 102 in the Nancy area (Lorraine), and on DOY 92 and 93 in the Bordeaux area (SW France) in 2006 and 2007 respectively (Lebourgeois, 2007). In those $2 \mathrm{y}$, at INRA-Nancy, the first production of ascospores was recorded at 126 and 113 and production of inoculum by chasmothecia was maximal at 148.9 and 144.5. Similarly, lesion induction on trap oak seedlings at INRA-Bordeaux was maximal on day of the year 144 and 136 respectively in 2006 and 2007. Thus, maximal ascospore production occurred about 30-50 d after budburst and the first growth unit of oaks was produced in a context of very low ascospore availability in those $2 \mathrm{y}$ and in 2 contrasted locations. This is probably the main reason explaining the low incidence of oak mildew on the first growth unit of oak. Flag shoots are alternative source of oak mildew inoculum in spring; however they are very infrequent for oak mildew in France, with, in a country-wide survey, presence in $40 \%$ of the stands but an estimated frequency of 0.005 per seedling in young naturally regenerated oak stands (Marçais, unpublished data). Inoculum is thus available mainly for the second growth unit that is produced in the second half of June (day of the year 165-180).

Local adaptation results from a balance between natural selection and gene flow; it will occur whenever selection is stronger than gene flow. The apparent lack of genetic differentiation for the timing of ascospore production by chasmothecia in E. alphitoides could thus result from several reasons. Few data exist on the strength of gene flow in E. alphitoides. As it is efficiently dispersed by numerous air-borne conidiospores, this pathogen probably experiences high gene flow. Indeed, following its first mention in France and Spain in 1907, oak mildew was recorded all over Europe within a few years (Foex, 1941; Woodward et al., 1929). However, this putatively high gene flow does not prevent populations of $E$. alphitoides to be locally adapted to their host at the scale of a few kilometres, with isolates sampled on an oak tree performing better on that individual than on other oak trees (Roslin et al., 2007). On the other hand, oak mildew mentioned in Europe since only 1907 (Foex, 1941), is most likely an exotic species which performed a host shift (Raymond, 1927). Introduced species often show a reduced genetic diversity, which can be a limiting factor for selection. A hundred years of evolution was maybe too short for the pathogen to have adapted to its new hosts. However, evolution of fungal pathogens has been known to occur very quickly when the selective pressure is strong as can be seen with appearance of virulent strains that infect hosts with complete resistance within a few years to 1-2 decades (Mc Donald and Linde, 2002). It can be hypothesized that the selective pressure for an adaptation of the pathogen phenology to host phenology is not very strong. Although the deterministic growth of oaks and the fact that oak leaves are susceptible to $E$. alphitoides only during their development (Edwards and Ayres, 1982) might suggest that a good synchrony between tree and pathogen phenology is critical for the pathogen, this may not be the case. Indeed, oaks show a very high variability in their phenology with a lag of $20 \mathrm{~d}$ between the budburst of the earliest and latest individuals of a $Q$. robur full-sib family (ScottiSaintagne et al., 2004). Moreover, they produce several growth units during the season, the second one being produced in the second half of June and the third in August. Thus, oak mildew genotypes that produce their spores after the first oak growth unit is mature might not be counter-selected. Moreover, chasmothecia are not the only inoculum source of oak mildew in spring as the pathogen is known to be also able to overwinter in infected buds (Kerling, 1966) which should reduce the importance of a good synchrony between chasmothecia and oak phenology for E. alphitoides fitness.

Until recently, data on the relative importance of ascospores in the infection of powdery mildew diseases was rather scarce (Braun, 1995). Ascospore infections have been confirmed for only a limited number of species (Braun, 1995; Jailloux et al., 1998; Mmbaga, 2000; Pearson and Gadoury, 1987). Our results demonstrate that for oak powdery mildew, ascospores released by chasmothecia can be a major source of primary inoculum in spring.

Nevertheless, it is clear that severity of oak powdery mildew would be strongly affected if inoculum was available during the development of the first host growth unit as would be the case if production of ascospores by E. alphitoides chasmothecia and of oak budburst showed synchrony. From our study, temperature is suggested to be an important factor driving production of ascospores by chasmothecia, as shown by effects of overwintering in locations experiencing mild or cold winters. Temperature is also an important environmental cue for tree phenology, especially oaks (Spark and Carey, 1995). However, increasing temperature during the winter may have different impact on the phenology of the host and their parasites, as was shown on insect defoliators of trees (Van Asch and Visser, 2007; Visser and Holleman, 2001). Thus, in the context of increasing winter temperature linked to climate change, it might be that $E$. alphitoides inoculum becomes more available during its host budburst. This could explain why severe infections of the first growth unit by oak mildew were observed in several years of the last decade in SW France. To test that hypothesis, we need to understand how production of ascospores by $E$. alphitoides chasmothecia is controlled by local environment. As our results suggest that $E$. alphitoides shows little or no genetic differentiation for this trait across a large part of Europe, species-level modelling of the time of optimum ascospore production as a function of environmental variables (especially temperature) should be possible.

Acknowledgements: We wish to thank Olivier Caël and Xavier Capdevielle for their technical assistance.

\section{REFERENCES}

Baker R.H.A., Sansford C.E., Gioli B., Miglietta F., Porter J.R., and Ewert F., 2005. Combining a disease model with a crop phenology model to assess and map pest risk: Karnal bunt disease (Tilletia indica) of wheat in Europe. In: Alford D.V. and Backhaus G.F. (Eds.), Plant 
protection and plant health in Europe: introduction and spread of invasive species, Humboldt University, Berlin, Germany, pp. 89-94.

Biere A. and Honders S.J., 1996. Impact of flowering phenology of Silene alba and $S$. dioica on susceptibility to fungal infection and seed predation. Oikos 77: 467-480.

Braun U., 1995. The powdery mildews (Erysiphales) of Europe, Gustav Fischer Verlag, Jena, Germany.

Bréda N., Granier A., and Aussenac G., 1995. Effects of thinning on soil water balance and trees water relations, transpiration and growth in an oak forest (Quercus petraea). Tree Physiol. 15: 295-306.

Cipollini D., 2002. Variation in the expression of chemical defenses in Alliaria petiolata (Brassicaceae) in the field and common garden. Am. J. Bot. 89: 1422-1430.

Cleland C.C., Chuine I., Menzel A., Mooney H.A., and Schwartz M.D., 2007. Shifting plant phenology in response to global change. Trends Ecol. Evol. 22: 357-365.

Desprez-Loustau M.L. and Dupuis F., 1994. Variation in the phenology of shoot elongation between geographic provenances of maritime pine (Pinus pinaster) - implications for the synchrony with the phenology of the twisting rust fungus, Melampsora pinitorqua. Ann. Sci. For. 51: $553-568$

Desprez-Loustau M.L., Belrose V., Bergot M., Capron G., Cloppet E., Husson C., Piou D., Reynaud G., Robin C., and Marçais B., 2008. Simulating effects of climate change on geographical range and impact of forest pathogenic fungi. In Desprez-Loustau (Coord.), Forests, carbon cycle and climate change, Editions Quae, coll. Science Update, pp. 258-288 (in press).

Ducousso A., Guyon J.P., and Krémer A., 1996. Latitudinal and altitudinal variation of bud burst in western populations of sessil oak (Quercus petraea (Matt) Liebl). Ann. Sci. For. 53: 775-782.

Edwards M.C. and Ayres P.G., 1982. Seasonal changes in resistance of Quercus petraea (sessile oak) leaves to Microsphaera alphitoides. Transactions of the British Mycological Society 78: 569-571.

Foex M.E., 1941. L'invasion des chênes d'Europe par le blanc ou oidium. Rev. Eaux For. 79: 338-349.

Kerling L.C.P., 1966. The hibernation of the oak mildew. Acta Botanica Neerlandica 15: 76-83.

Lebourgeois F., 2007. The sensitivity of forest ecosystems to climate: what Renecofor has taught us. Rendez-Vous Techniques, 15: 64-68.

Jailloux F., Thind T., and Clerjeau M., 1998. Release, germination and pathogenicity of ascospores of Uncinula necator under controlled conditions. Can. J. Bot. 76: 777-781.

Jensen J.S. and Hansen J.K., 2008. Geographical variation in phenology of Quercus petraea (Matt.) Liebl and Quercus robur L. oak grown in a greenhouse. Scand. J. For. Res. 23: 179-188.

Mc Donald B.A. and Linde C., 2002 Pathogen population genetics, evolutionary potential, and durable resistance. Ann. Rev. Phytopathol. 40: 349-379.
Marçais B. and Bréda N., 2006. Role of an opportunistic pathogen in the decline of stressed oak trees. J. Ecol. 94: 1214-1223.

Mmaga M.T., 2000. Winter survival and source of primary inoculum of powdery mildew of dogwood in Tenessee. Plant Dis. 84: 574-579.

Mougou A., Dutech C., and Desprez-Loustau M.L., 2008. New insights into the identity and origin of the causal agent of oak powdery mildew in Europe. For. Pathol. 38: 275-287.

Oleksyn J., Modrzynski J., Tjoelker M.G., Zytkowiak R., Reich P.B., and Karolewski P., 1998. Growth and physiology of Picea abies populations from elevational transects: common garden evidence for altitudinal ecotypes and cold adaptation. Funct. Ecol. 12: 573-590.

Pearson R.C. and Gadoury D.M., 1987. Cleistothecia, the source of primary inoculum for grape powdery mildew in New York. Phytopathology 77: 1509-1514

Penman L.N. and Annis S.L., 2005. Leaf and flower blight caused by Monilinia vaccinii-corymbosi on lowbush blueberry: effects on yield and relationship to bud phenology. Phytopathology 95: 1174-1182.

Raymond J., 1927. Le "blanc" du chêne. Annale des Epiphyties 13: 94129.

Roslin T., Laine A.L., and Gripenberg S., 2007. Spatial population structure in an obligate plant pathogen colonizing oak Quercus robur. Funct. Ecol. 21: 1168-1177.

Scotti-Saintagne C., Bodénès C., Barreneche T., Bertocchi E., Plomion C., and Kremer A., 2004. Detection of quantitative trait loci controlling bud burst and height growth in Quercus robur L. Theor. Appl. Genet. 109: 1648-1659.

Soutrenon A., 1998. Une experimentation pluri-annuelle confirme l'impact de l'oïdium sur de jeunes sujets. Les cahiers du DSF, 1-2000 (la santé des forets [France] en 1997), Min. Agri. Pêche (DERF), Paris, 93-94.

Spark T.H. and Carey P.D., 1995. The response of species to climate over two centuries: an analysis of the Marsham phenological record, 1736-1947. J. Ecol. 83: 321-329.

Thomas F.M., Blank R., and Hartmann G., 2002. Abiotic and biotic factors and their interactions as causes of oak decline in central Europe. For. Pathol. 32: 277-307.

Van Ash M. and Visser M.E., 2007. Phenology of forest caterpillars and their host trees: the importance of synchrony. Ann. Rev. Entomol. 52: $37-55$

Visser M.E. and Holleman L.J.M., 2001. Warmer springs disrupt the synchrony of oak and winter moth phenology. Proceedings of the Royal Society London Series B 268: 89-94.

Woodward R.C., Waldie J.S.L., and Steven H.M., 1929. Oak mildew and its control in forest nurseries. Forestry $3: 38-56$. 